\title{
Examining Challenging Factors of Tourism Entrepreneurship in Oman using PLS-SEM
}

\author{
Omar Ali Al Badi \& Firdouse Rahman Khan \\ Faculty of Business, Sohar University, Sultanate of Oman \\ Email: ${ }^{1}$ omar_albadi89@icloud.com, ${ }^{2}$ firdouse@yahoo.co.uk
}

Article History: Received on $12^{\text {th }}$ Mar. 2020, Revised on $17^{\text {h }}$ Apr. 2020, Published on $11^{\text {th }}$ July 2020

\begin{abstract}
Purpose of the study: The objectives of the study were to critically examine the challenges faced by entrepreneurs in tourism business in establishing their businesses in Oman; to critically analyze whether the entrepreneurs in the tourism business are motivated to establish tourism business in Oman and to critically analyze the prospects for entrepreneurs to venture into the tourism sector in Oman.

Design/Methodology: The data was collected through a well-defined questionnaire through which 241 tourism entrepreneurs from Oman, including unemployed youth who were interested in tourism were selected, on a random sampling basis. Structural Equation Modelling through Smart PLS was used to analyze the data.

Findings: The results of the research show that the initial capital, working capital, and good location are the essential factors required to establish a tourism business in Oman. It was confirmed that the prevailing rules and regulations are strict and rigid to start a tourism business in Oman and it takes lots of time to start the operation of tourism businesses; seeking labor clearance procedure is NOT simple for tourism. Cultural values and physical working conditions do not encourage tourism-related businesses and non-preference of spouse from the tourism sector is another major constraint for Omanis in taking up tourism businesses.

Implications: It was suggested that the Government should provide strategic support to the tourism-related entrepreneurs; the Government should provide financial guidance to encourage tourism entrepreneurs irrespective of their ages. Governmental licensing authorities and all licenses to set up tourism businesses need to be obtained in one place. The Government should invest in super-structure projects to enhance the scope of tourism. Training must be provided by the Government to enhance the tourism business in Oman. Originality: This is the study of its kind and no research was carried out ever before to study solely the challenges of tourism entrepreneurship in Oman.

Keywords: Tourism, Challenges, Tourism Entrepreneurship, Financial Constraints, Technological Support, Government Support, Procedures and Formalities.
\end{abstract}

\section{Introduction}

Entrepreneurship is the process of setting up new businesses in an innovative way. The term 'Tourism Entrepreneurship' was first used to refer those entrepreneurs who were involved in the process of venturing into tourism businesses in Oman (Khan \& Krishnamurthy, 2016). It is a known fact that tourism is one of the rapidly growing industries around the globe. Oman is no exception to it. The Sultanate of Oman is one of the Gulf Cooperation Council (GCC) countries in the Middle East which has progressive and steady economic growth. It is an oil-based economy. Expecting the run out of its oil resources in less than 20 years, the Government of Oman has started to diversify its economy. Tourism is one of the sectors accelerating the economic growth of Oman which can effectively help Oman to attain its economic goal of diversification from the Oil \& Gas (O\&G) sector (AlMaimani \& Johari, 2014). Due to the important role played by the tourism sector in the economic growth of the country, the Government of Oman started paying more attention to the tourism sector and effective strategies for the sustainable development of the sector are in progress. The entrepreneurs in the field of tourism are highly encouraged. Oman is paying more attention to tourism entrepreneurship (Alani, Khan, \& Manuel, 2017).

In 2013, 100,894,00 jobs were provided in the tourism industry, and globally it is estimated that to grow to $3.5 \%$ of total employment i.e. 126,257,000 jobs would be available by 2024 (Pandow \& Omar, 2019) due to the increasing visitors to Oman from different parts of the world.

Entrepreneurship is a proactive approach that boosts up the performance and productivity of an organization. The role of the tourism industry is incredible in Oman as it is contributing more than $7 \%$ and is increasing over time (Al Abri, Abdel-Hady, \& Al-Abaidani, 2016). The economy of Oman is majorly dependent on oil-related products like other gulf countries but since last few decades Oman is shifting its economy towards non-renewable resources and in this tourism is expanding and stabilizing the economy of Oman as having beautiful scenes of nature and places as well (Sokhalingam, Manimekalai, \& Sudhahar, 2013).

Oman Tourism strategy has been made in alignment with Oman 2040 vision in which Oman will give more attention to the sector of tourism. The sultanate of Oman aims to generate about 535,000 jobs in Tourism 
Sector by 2040 (THR Innovative Tourism Advisors, 2016). Considering this, there is a dire need to shift the burden of the economy as the Oman tourism industry has great potential. However, there are many challenges faced by tourism entrepreneurship in Oman by the private sector also by the Government (Atef \& Al-Balushi, 2015). The lack of cooperation between the government sector and the private sector is also one of the challenges.

\section{Statement of the Problem}

The key area of concern is the needs and expectations of the tourist due to the lack of strategic alignment. Another glaring challenge is that the media is not supporting tourism. The government also has to focus on the prices of hotels available in Oman. There is also a need for infrastructure in Oman to modern and attractive reformatting. Lack of commitment by the tour operator is also a challenge faced by tourism (Khan \& Krishnamurthy, 2016). The contribution of income to GDP by the tourism sector has improved mobilizations of investment and development of local economies at present and expected to bring more employment by tourism SMEs in the future (Aulia, 2016). Though raising awareness among the investors and stakeholders is beneficial, for the sustainable development of tourism, the implementation of a clear strategy is required. The present status of the tourism sector is that the Omanis are facing different challenges as seen above. The infrastructure of Oman has needed to be reformed to gain the attraction of tourists (Sazegar, Forouharfar, Hill, \& Faghih, 2018).

\section{Research Questions}

Therefore, the following questions arise:

1. What are the challenges faced by entrepreneurs in the tourism business in establishing their businesses in Oman?

2. What are the factors motivating the entrepreneurs in the tourism business to establish a tourism business in Oman?

Based on the above, the following research objectives were defined:

\section{Research Objectives}

The Objectives were

1. To critically examine the challenges faced by entrepreneurs in the tourism business in establishing their businesses in Oman

2. To critically analyze whether the entrepreneurs in the tourism business are motivated to establish tourism business in Oman

\section{Review of Literature \\ Reason for Starting up Tourism Business}

Oman is critically considering tourism as the main sector for development as it started diversifying its economic resources from simply depending on the oil and gas industry by increasing visitors from all over the world (AlMaimani \& Johari, 2014). Oman has the three Ss of tourism viz. Sun, Sea, and Scenery and therefore the country has great potential for tourism and it just needs the support of the private and government sector that make it a beneficial industry to reduce the burden from the oil industry (Henderson, 2015). Oman has several spatial environments such as plains, mountains, deserts, oases, islands, and attractive coasts across the country, prospective features for the tourism industry (Mansour, Al-Awhadi \& Al-Hatrushi, 2020). The diversification of Oman's Oman from an oil-based economy to tourism is expanding and having a good scope of stabilizing the economy of Oman (Al Abri, Abdel-Hady, \& Al-Abaidani, 2016). National Tourism Development Agency, Oman is preserving the cultural integrity of Oman and is following sustainable development to increase its economy marinating the natural environment with less damage done by sustainable strategies of ecotourism (Alrawadieh, Karayilan, \& Cetin, 2019). Tourism entrepreneurship in Oman is increasing due to the availability of multiple job opportunities and cultural variability in-country (Sotiriadis \& Apostolakis, 2015). Further, the success of the entrepreneurs of Oman needs to focus on entrepreneurship education in relates to Oman Tourism and further emphasized that it should be started at the school level (Al Harthi, 2017; Alsawafi, 2016). Omani nationals should be taught some foreign languages primarily English as they find it difficult to communicate with international tourists (Al Mahrooqi, 2012). Oman focuses on gender equality as well as women empowerment but social concerns that bind them from doing tourism-related businesses but of late women living in mountains and rural areas were inspired to move beyond their traditional values and willing to take up innovative businesses (Ghouse, McElwee, Meaton, \& Durrah, 2017).

\section{Government Support}


The lack of cooperation between the Government sector and the private sector due to which there is no strategic alignment. The private sector should join with the Government in the improvement of the tourism industry in Oman by analyzing the constraints faced by entrepreneurs in the tourism sector (Ali, Nusair, Alani, Khan, \& Al Badi, 2017). The private sector should join with the Government in the improvement of the tourism industry in Oman by analyzing the constraints faced by entrepreneurs in the tourism sector (Atef \& Al-Balushi, 2015). Different challenging factors reducing the performance, productivity, and growth of the tourism industry in Oman and the government's role in reducing the negative impact on the tourism industry of Oman (Yuksel, 2014).

The challenges faced by the tourism industry in Oman could be reduced through the effective rules and regulations related to tourism by the Government of Oman (Atef \& Al-Balushi, 2015).

Though non-discrimination of gender and physical working condition is good, tourism in Oman is discouraged by high risks of accidents in Oman, non-tourism spouse preferences, and traditional values of Oman and because of this, tourism-related entrepreneurial activities have been thwarted (Khan \& Krishnamurthy, 2016).

\section{Technological Support}

Technological advancements have changed the way we travel, and these new developments promise an even more interactive and exciting experience and the Ministry of Tourism has been establishing the infrastructure for the tourism industry to leverage tourism in the local and international market (Al Muqbali, 2006). Social media, apps, blogs, etc. have an important role to play in the planning of a tour, thus tourism adapting business models and product offerings to attract this coveted target (Vidal, 2019). Internet applications through its developments have drastically changed the future projects into e-tourism and demonstrate critical influences on the tourism industry structure (Buhalis \& Law, 2008). Applications and interaction of information and communications technologies (ICT) providing prospects to the tourism sector (Frew, 2000). The wearable devices have changed the behavior of tourists to very high extent cases in Tourism (Atembe, 2015). Advances in mobile technology creating innovative experiences for tourists, fostering a sustainable competitive advantage for tourism destinations and tourism-related suppliers, and creating sustainable smart tourism (Kim \& Kim, 2017). Reform in the infrastructure of Oman using technological advancement is a must to gain the attraction of tourists (Sazegar et al., 2018). With the internet revolutionizing global tourism, technological changes enhance the roadmap to the tourism industry and its marketing (Brdesee, 2013). Internet of Things, Big Data, Artificial Intelligence, Virtual Reality, and Augmented Reality can be applied to the tourism sector (Ozturk, 2020). Novel business models combined with state-of-the-art technology can play a crucial role in increasing tourism demand and also ensure sustainable growth to avoid the deteriorating effects on both the social and natural habitat (Urbančič et al., 2020).

\section{Financial Constraints}

The major challenge faced by the tourism sector in Oman is due to poor financial support and weak economic conditions (Al Riyami, Scott, Ragab and Jafari, 2017). A major constraint for a tourism establishment in Oman is project funding, and managing the tourism business (Al Harthi, 2017).

The Government should provide financial and strategic support to the tourism entrepreneurs to support the tourism industry which can generate new jobs and could uplift economic development (Alani et al., 2017). Omani youth who have innovative ideas need financial support as a successful tourism entrepreneur would be able to provide employment opportunities to many more (Sokhalingam, Manimekalai, \& Sudhahar, 2013). Opportunities for income-generating activities should be offered to local people as a part of tourism development to win the local support but due to lack of initial investment, Omanis lack behind in the tourism sector (Subramoniam, Al-Essai, Al-Marashadi \& Al-Kindi, 2010). Reluctance by financial institutions to lend money to rural entrepreneurs binds them from doing tourism-related businesses (Ghouse, McElwee, Meaton, \& Durrah, 2017). The lack of sufficient and adequate financial support constitutes a serious barrier to budding entrepreneurs in tourism-related businesses (Al Badi, Malik, \& Gastli, 2009).

\section{Procedure and Formality difficulties}

For the benefit of the growth of the tourism industry in Oman, the decision-making process in relates to the tourism sector needs lots of improvement at the local, regional and international levels with the support of the World Times organization (Adewale, 2016). The procedures and time lag is very high in the tourism industry (Binoy, 2017). The procedural formalities for the establishment of a new venture are cumbersome for a new entrepreneur in Oman and act as a major barrier (Al Buraiki \& Khan, 2018). An entrepreneur who 
ventures into the business finds it very difficult to cope up with the official procedures as it is complicated and it needs to be simplified (Al Hadhrami, 2006). Visa policies and the rules and regulations, nonavailability of trained tour guides, improper maintenance of hotels were the prime challenges (Aulia, 2016; Baporikar, 2017).

\section{Challenges faced by Omani Tourism Entrepreneurs}

Human capital, support system, lack of technology, government policies, shortage of finance are the major challenges in the way of entrepreneurship in Oman (Sotiriadis \& Apostolakis, 2015). Tourism is not considered as a respectable and a good choice for women in Oman and there is a decreased threshold of girls joining Tourism studies in Oman. Thus encourage girls to venture into tourism and empower women in training and tourism entrepreneurship (Al Abri, Abdel-Hady, \& Al-Abaidani, 2016; Alsawafi, 2016). Nondiscrimination of gender, physical working conditions and promotional opportunities encourage people to venture into the tourism sector whereas high risks of accidents in Oman, non-tourism spouse preferences, and traditional values of Oman discouraged them (Khan \& Krishnamurthy, 2016). The tourist guide profession is not considered as a prestigious profession in the society of Oman but (Alani et al., 2017) and suggested for implementing specialized courses by the government in relates to tourism. The tourism sector in Oman is suffering due to factors such as strict policies, financial performance, and lack of support from the government of Oman (Stanković \& Đukić, 2009). Lack of commitment by the tour operator is also a challenge faced by tourism (Saleh \& Alalouch, 2015). Ecotourism is considered to be an effective sustainability approach towards Oman economic development and less focus is on tourism (Aulia, 2016). Also, focus on the entrepreneurship education of tourism needed in Oman as schools do not put the focus on teaching students about tourism and it affects the economy (Alrawadieh et al., 2019).

\section{Hypotheses}

After going through the above review of literature, the present study considers factors such as Reasons for starting up tourism business, Procedure \& Formality difficulties, Financial constraints, Technology factors, Government support factors and the Challenges faced by tourism entrepreneurs and therefore, the following hypotheses were framed:

1. Procedural formalities and financial constraints are the typical challenges faced by tourism entrepreneurs in Oman.

2. Entrepreneurs are motivated to establish a tourism business in Oman.

\section{Research Methodology}

The data was collected through a well-defined questionnaire through which 241 tourism entrepreneurs from Oman, including unemployed youth who were interested in tourism were selected, on a random sampling basis. Structural Equation Modelling through Smart PLS was used to analyze the data.

\section{Findings}

Table 1

Demographic details of the respondents

\begin{tabular}{|l|l|c|c|}
\hline Characteristics & & Frequency & $\%$ \\
\hline \multirow{4}{*}{ Nationality } & Omani & 224 & 92.9 \\
\cline { 2 - 4 } & Non-Omani & 17 & 7.1 \\
\hline \multirow{5}{*}{ Age } & Male & 78 & 32.4 \\
\cline { 2 - 4 } & Female & 163 & 67.6 \\
\hline & $20-30$ years & 164 & 68 \\
\cline { 2 - 4 } & $30-40$ years & 58 & 24.1 \\
\cline { 2 - 4 } & $40-50$ years & 13 & 5.4 \\
\cline { 2 - 4 } & $50-60$ years & 5 & 2.1 \\
\cline { 2 - 4 } & $>60$ years & 1 & 0.4 \\
\cline { 2 - 4 } & $20-30$ & 164 & 68 \\
\hline \multirow{5}{*}{ Marital Status } & Single & 153 & 63.5 \\
\cline { 2 - 4 } & Married & 3 & 35.3 \\
\cline { 2 - 4 } & Divorce/d & 30 & 46.9 \\
\hline \multirow{5}{*}{ College } & Community College & 8 & 3.1 \\
\cline { 2 - 4 } & College of Business Administration & 16 & 12.5 \\
\cline { 2 - 4 } & College of Education & 25.0 \\
\cline { 2 - 4 } & College of Engineering & 8 & 12.5 \\
\cline { 2 - 4 } & College of Pharmacy & 3 & 16 \\
\hline
\end{tabular}




\begin{tabular}{|c|c|c|c|}
\hline \multirow{4}{*}{ Qualification } & Secondary Or Below & 18 & 7.5 \\
\hline & Diploma & 91 & 37.8 \\
\hline & Degree & 123 & 51 \\
\hline & Others & 9 & 3.7 \\
\hline \multirow{2}{*}{ Employment Status } & Having a business & 77 & 32 \\
\hline & Not having business & 164 & 68 \\
\hline \multirow{11}{*}{ Governorate } & Muscat & 18 & 7.5 \\
\hline & Musandam & 8 & 3.3 \\
\hline & Dhofar & 10 & 4.1 \\
\hline & Ash Sharqiyah South & 5 & 2.1 \\
\hline & Ash Sharqiyah North & 18 & 7.5 \\
\hline & Al Wusta & 3 & 1.2 \\
\hline & Al Buraimi & 9 & 3.7 \\
\hline & Al Batinah South & 20 & 8.3 \\
\hline & Al Batinah North & 131 & 54.4 \\
\hline & Al Dhahirah & 14 & 5.8 \\
\hline & Al Dakhliyah & 5 & 2.1 \\
\hline \multirow{12}{*}{ Residing at } & Sohar & 69 & 28.6 \\
\hline & Shinas & 4 & 1.7 \\
\hline & Saham & 41 & 17 \\
\hline & Liwa & 4 & 1.7 \\
\hline & Barka & 11 & 4.6 \\
\hline & Muscat & 5 & 2.1 \\
\hline & Ibri & 6 & 2.5 \\
\hline & Suwaiq & 17 & 7.1 \\
\hline & Nizwa & 4 & 1.7 \\
\hline & Yanqul & 7 & 2.9 \\
\hline & Al Khabourah & 9 & 3.7 \\
\hline & Others & 64 & 26.6 \\
\hline
\end{tabular}

Source: Questionnaire

Table 3

Factors required to start a tourism business

\begin{tabular}{|c|c|c|c|c|c|c|c|c|c|}
\hline \# & Factors & $\begin{array}{c}\text { Rank } \\
1\end{array}$ & $\begin{array}{c}\text { Rank } \\
2\end{array}$ & $\begin{array}{c}\text { Rank } \\
3\end{array}$ & $\begin{array}{c}\text { Rank } \\
4\end{array}$ & $\begin{array}{c}\text { Rank } \\
5\end{array}$ & $\begin{array}{c}\text { Rank } \\
6\end{array}$ & Total & $\begin{array}{c}\mathrm{K}-\mathrm{S} \\
\text { value }\end{array}$ \\
\hline 1 & Initial Capital finance & 110 & 27 & 21 & 10 & 11 & 11 & 190 & 0.1863 \\
\hline 2 & $\begin{array}{l}\text { Working capital } \\
\text { finance }\end{array}$ & 32 & 66 & 15 & 5 & 5 & 8 & 131 & 0.1216 \\
\hline 3 & Training & 2 & 12 & 26 & 23 & 5 & 6 & 74 & 0.0516 \\
\hline 4 & Workforce & 4 & 15 & 6 & 15 & 13 & 7 & 60 & 0.0397 \\
\hline 5 & Good location & 17 & 29 & 62 & 15 & 17 & 22 & 162 & 0.1179 \\
\hline 6 & Government support & 4 & 21 & 21 & 36 & 21 & 21 & 124 & 0.0759 \\
\hline 7 & $\begin{array}{l}\text { Experience in the line } \\
\text { of business }\end{array}$ & 11 & 23 & 18 & 21 & 16 & 22 & 111 & 0.0732 \\
\hline 8 & $\begin{array}{l}\text { Education / Technical } \\
\text { Qualification }\end{array}$ & 9 & 9 & 8 & 23 & 9 & 15 & 73 & 0.0461 \\
\hline 9 & Family Support & 10 & 4 & 11 & 13 & 17 & 28 & 83 & 0.0445 \\
\hline 10 & $\begin{array}{l}\text { Professional Contacts } \\
\text { in the line of business }\end{array}$ & 6 & 11 & 14 & 27 & 16 & 22 & 96 & 0.0558 \\
\hline
\end{tabular}




\begin{tabular}{|c|l|c|c|c|c|c|c|c|c|}
\hline 11 & $\begin{array}{l}\text { Financial Institution } \\
\text { support / backup }\end{array}$ & 7 & 5 & 12 & 8 & 18 & 16 & 66 & 0.0378 \\
\hline 12 & $\begin{array}{l}\text { Recommendation from } \\
\text { Big shots in the same } \\
\text { line of business }\end{array}$ & 5 & 0 & 6 & 6 & 10 & 14 & 41 & 0.0210 \\
\hline 13 & Self confidence & 17 & 15 & 11 & 28 & 22 & 16 & 109 & 0.0722 \\
\hline 14 & Straight forwardness & 4 & 8 & 8 & 51 & 24 & 95 & 95 & 0.0399 \\
\hline 15 & $\begin{array}{l}\text { Religious } \\
\text { consciousness }\end{array}$ & 5 & 1 & 4 & 2 & 9 & 9 & 30 & 0.0166 \\
\hline & TOTAL & 239 & 242 & 243 & 240 & 240 & 241 & 243 & \\
\hline
\end{tabular}

So, based on the values obtained from the Kolmogorov-Smirnov test, 'Initial Capital' was ranked first (0.1863), 'working capital' was ranked second (0.1216); 'Good Location' was ranked third (0.1179); 'Government Support' was ranked fourth (0.0759); 'Experience in the line of business' was ranked fifth (0.0732) and 'Self-confidence' was ranked sixth (0.0722).

The details of the latent variables (factors) and apparent variables (sub-factors) are given in Table 3.

Table 3

Details of Latent variables and Apparent variables

\begin{tabular}{|c|c|c|}
\hline $\begin{array}{l}\text { Factors (Latent } \\
\text { variables) }\end{array}$ & & $\begin{array}{c}\text { Sub-factors } \\
\text { (Apparent variables) }\end{array}$ \\
\hline \multirow{10}{*}{$\begin{array}{llr}\text { Reason } & \text { for } \\
\text { starting up } & \text { a } \\
\text { Tourism } & & \\
\text { business } & & \end{array}$} & s1 & Oman has a great scope to start a tourism-related business. \\
\hline & s2 & Starting a tourism-related business could help Oman's Economy \\
\hline & s3 & $\begin{array}{l}\text { Oman has the three necessaries for tourism - Sun, Sea, and Scene to } \\
\text { justify the scope of tourism business }\end{array}$ \\
\hline & s4 & There are lots of chances to venture into the tourism business \\
\hline & s5 & $\begin{array}{l}\text { Many tourists visiting Oman will help in the success of the tourism } \\
\text { business }\end{array}$ \\
\hline & s6 & Oman has nice tourist places to visit throughout the year \\
\hline & s7 & Women entrepreneurs lack moral support towards a tourism start-ups \\
\hline & s8 & $\begin{array}{l}\text { Women entrepreneurs do not get recognition/support from the society in } \\
\text { starting a business related to tourism }\end{array}$ \\
\hline & s9 & $\begin{array}{l}\text { Women entrepreneurs lack initial capital to start a tourism-related } \\
\text { business }\end{array}$ \\
\hline & s10 & $\begin{array}{l}\text { Women venturing in the tourism industry could help in improving the } \\
\text { economy of the country }\end{array}$ \\
\hline \multirow{8}{*}{$\begin{array}{l}\text { Procedures and } \\
\text { Formality } \\
\text { Difficulties }\end{array}$} & $\mathrm{p} 1$ & $\begin{array}{l}\text { Prevailing rules and regulations are strict and rigid to start a tourism } \\
\text { business in Oman }\end{array}$ \\
\hline & $\mathrm{p} 2$ & It takes lots of time to start the operation of tourism-related business \\
\hline & p3 & $\begin{array}{l}\text { The formalities set up by the municipality to start a tourism business is } \\
\text { cumbersome }\end{array}$ \\
\hline & $\mathrm{p} 4$ & There is no inter-link between the Governmental licensing authorities \\
\hline & p5 & All licenses to set up a tourism business can be obtained in one place \\
\hline & p6 & Procedures for establishing the tourism business are easier \\
\hline & p7 & Seeking labor clearance procedures are simple and logical for tourism \\
\hline & p8 & $\begin{array}{l}\text { Sufficient number of workers are sanctioned by the labor clearance } \\
\text { authorities for tourism business to encourage tourism in Oman }\end{array}$ \\
\hline \multirow{6}{*}{$\begin{array}{l}\text { Financial } \\
\text { constraints }\end{array}$} & f1 & Capital is a major concern in starting a tourism business \\
\hline & $\mathrm{f} 2$ & Costly hotels and restaurants discourage tourists from visiting Oman \\
\hline & f3 & $\begin{array}{l}\text { Financial Institutions (FIs) insist for guarantees from the borrowers of } \\
\text { tourism businesses }\end{array}$ \\
\hline & $\mathrm{f} 4$ & $\begin{array}{l}\text { Financial assistance available from FIs to start a tourism business in } \\
\text { Oman }\end{array}$ \\
\hline & f5 & It is easy to get a bank loan to start a tourism business in Oman \\
\hline & f6 & The loan amount provided by the FIs are sufficient to start a business \\
\hline
\end{tabular}




\begin{tabular}{|c|c|c|}
\hline & $\mathrm{f} 7$ & Bank loan installment amounts are within the repaying capacity \\
\hline & f8 & FIs take care of tourism businesses when they fail or become sick \\
\hline \multirow{8}{*}{$\begin{array}{l}\text { Technological } \\
\text { support factors }\end{array}$} & $\mathrm{t} 1$ & $\begin{array}{l}\text { The Press, Electronic media and Social media has not been giving enough } \\
\text { coverage to promote Tourism in Oman. }\end{array}$ \\
\hline & $\mathrm{t} 2$ & $\begin{array}{l}\text { Investors and stakeholders would be benefitted through tourism } \\
\text { promotion made by the media }\end{array}$ \\
\hline & $\mathrm{t} 3$ & $\begin{array}{l}\text { Specialized agencies are providing technical support to the tourism } \\
\text { business }\end{array}$ \\
\hline & $\mathrm{t} 4$ & $\begin{array}{l}\text { Information and Communication Technology (ICT) infrastructure in } \\
\text { Sultanate is optimal for tourism business }\end{array}$ \\
\hline & t5 & $\begin{array}{l}\text { Poor transportation facility is a big challenge in promoting tourism in } \\
\text { Oman }\end{array}$ \\
\hline & t6 & Infrastructure in Oman needs modernization to attract tourists \\
\hline & $\mathrm{t} 7$ & Technology improvement helps to increase tourist satisfaction \\
\hline & $\mathrm{t} 8$ & Using technology in tourism business can increase their income \\
\hline \multirow{9}{*}{$\begin{array}{l}\text { Government } \\
\text { support factors }\end{array}$} & g1 & $\begin{array}{l}\text { The Government should build synergy between private and public sector } \\
\text { to boost tourism business in Oman }\end{array}$ \\
\hline & g2 & $\begin{array}{l}\text { The Government should provide strategic support to the tourism-related } \\
\text { entrepreneurs }\end{array}$ \\
\hline & g3 & $\begin{array}{l}\text { The Government should provide Capital/Loans for tourism entrepreneurs } \\
\text { on easy terms \& conditions }\end{array}$ \\
\hline & g4 & $\begin{array}{l}\text { The Government should provide financial guidance to encourage tourism } \\
\text { entrepreneurs irrespective of their age }\end{array}$ \\
\hline & g5 & $\begin{array}{l}\text { Government-aided AL RAFD Fund helps tourism entrepreneurs from the } \\
\text { feasibility study until the inception and functioning of the businesses. }\end{array}$ \\
\hline & g6 & $\begin{array}{l}\text { Other loans (Bridge loan, working capital loan, etc.) can be obtained from } \\
\text { AL RAFD to expand the tourism business }\end{array}$ \\
\hline & g7 & $\begin{array}{l}\text { The Government should invest in super-structure projects to enhance the } \\
\text { scope for tourism }\end{array}$ \\
\hline & g8 & $\begin{array}{l}\text { Ministry of Tourism encourages/supports entrepreneurs to start a } \\
\text { business in Oman }\end{array}$ \\
\hline & g9 & $\begin{array}{l}\text { Training must be provided by the Government to enhance the tourism } \\
\text { business in Oman }\end{array}$ \\
\hline \multirow{8}{*}{$\begin{array}{l}\text { Challenges faced } \\
\text { by Tourism } \\
\text { entrepreneurs }\end{array}$} & $\mathrm{c} 1$ & $\begin{array}{l}\text { Lack of interest in tourism is a real challenge in the tourism business in } \\
\text { Oman }\end{array}$ \\
\hline & $\mathrm{c} 2$ & Lack of commitment and ignorance harms the tourism business \\
\hline & $\mathrm{c} 3$ & $\begin{array}{l}\text { Social factors such as age, level of education, population growth rate, etc. } \\
\text { are making a negative impact on the tourism business }\end{array}$ \\
\hline & $\mathrm{c} 4$ & $\begin{array}{l}\text { Financial factors such as initial capital, working capital affect the tourism } \\
\text { business }\end{array}$ \\
\hline & $\mathrm{c} 5$ & Gender discrimination prevails in tourism-related businesses \\
\hline & c6 & $\begin{array}{l}\text { Oman cultural values and physical working conditions do not encourage } \\
\text { tourism-related businesses }\end{array}$ \\
\hline & $\mathrm{c} 7$ & $\begin{array}{l}\text { The English language is a challenge as local Omanis find difficulty in } \\
\text { speaking with international tourists }\end{array}$ \\
\hline & $\mathrm{c} 8$ & $\begin{array}{l}\text { Spouse preferences from the non-tourism sector is a constraint for } \\
\text { Omanis in taking up tourism businesses }\end{array}$ \\
\hline
\end{tabular}

The latent variables are also known as constructs that will be tested along with the apparent variables using the measurement model. The conceptual model is shown in Figure 1.

\section{Figure 1}

Conceptual Model 


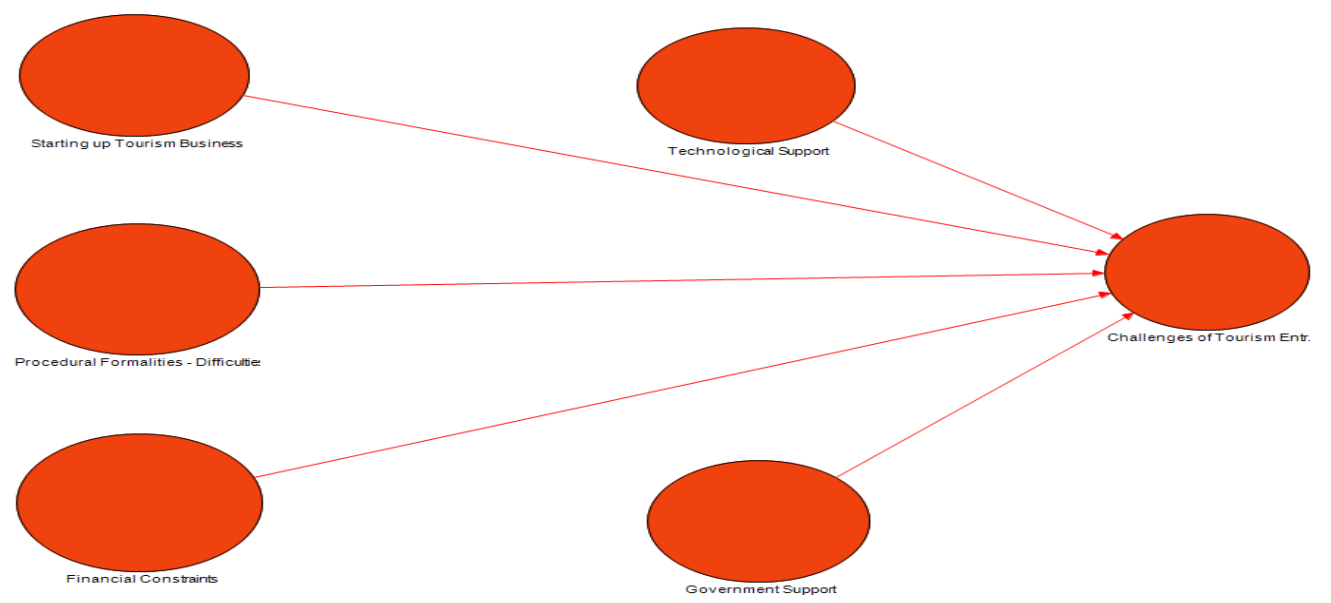

The structural model specifies the suppressed constructs. Tewari (2019) defined that measurement model, structural model, and structural regression equation - in the order are used to measure the quality of the model.

\section{Findings}

\section{Measurement Model}

Primarily the associations were displayed among the Starting up of Tourism Business factors, Government support factors, Technology support factors, Financial constraint factors, Procudeures and Formality difficulty factors, and Challenges faced by Tourism Entrepreneurship factors. To test the reliability of the measurement model, discriminant and convergent were validated (Tenenhaus, Vinzi, Chatelin, \& Lauro, 2005).

The coefficients and the values of loading were shown in Figure 2 through the obtained initial path model.

\section{Figure 2}

\section{Initial Path Model}

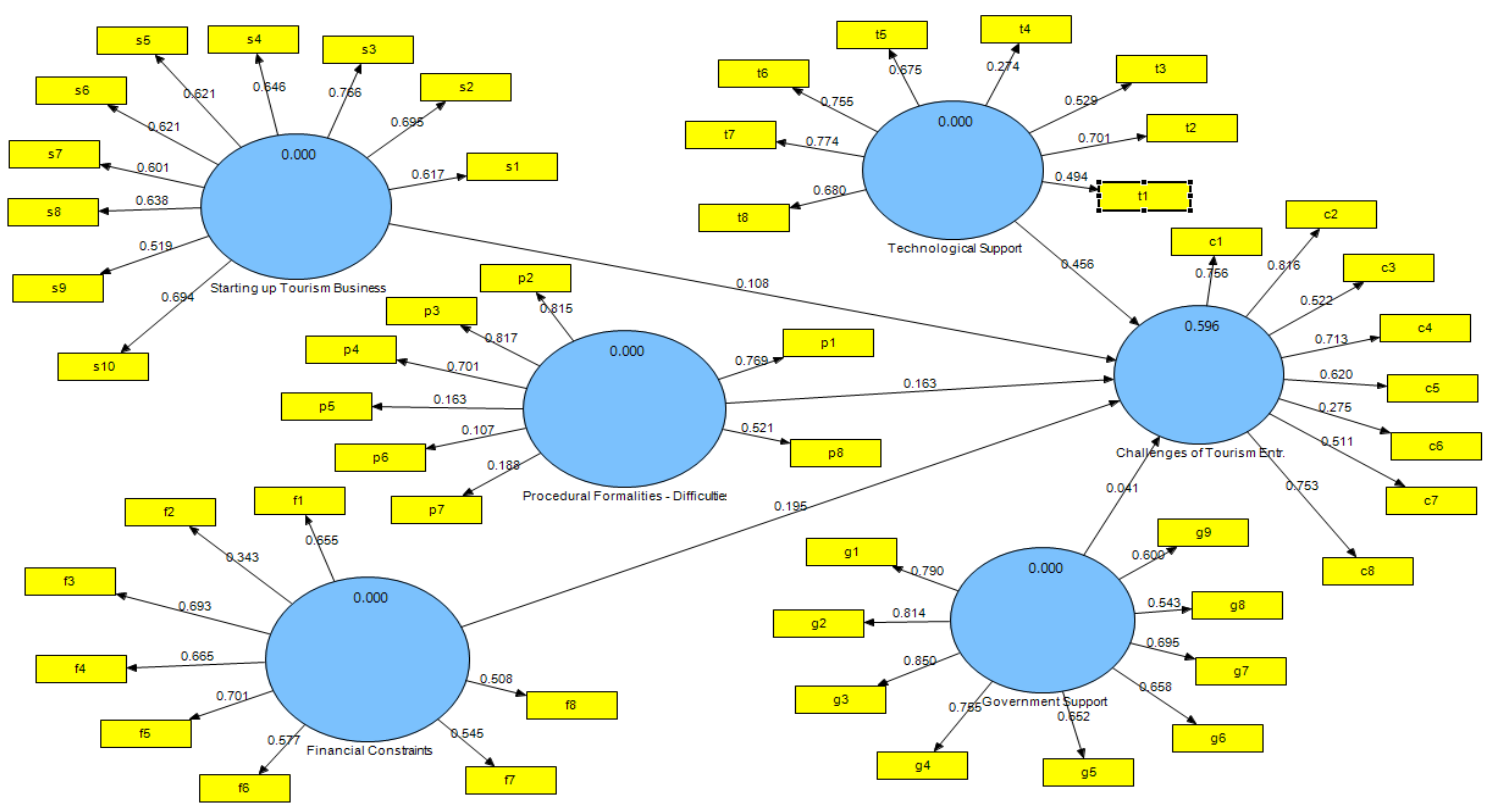

The reliability of the measurement model was validated by assessing the sub-factors reliability and the factor loadings. A minimum value of 0.45 can be considered preferable for loading of the sub-factors (Henderson,

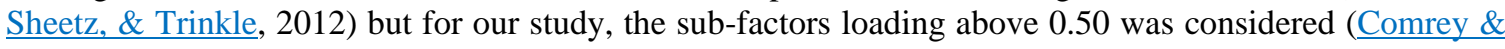
Lee, 2013) and those sub-factors with lesser loadings were removed from the model and the resulting final path model is shown in Figure 3.

\section{Figure 3}

Final Path Model 


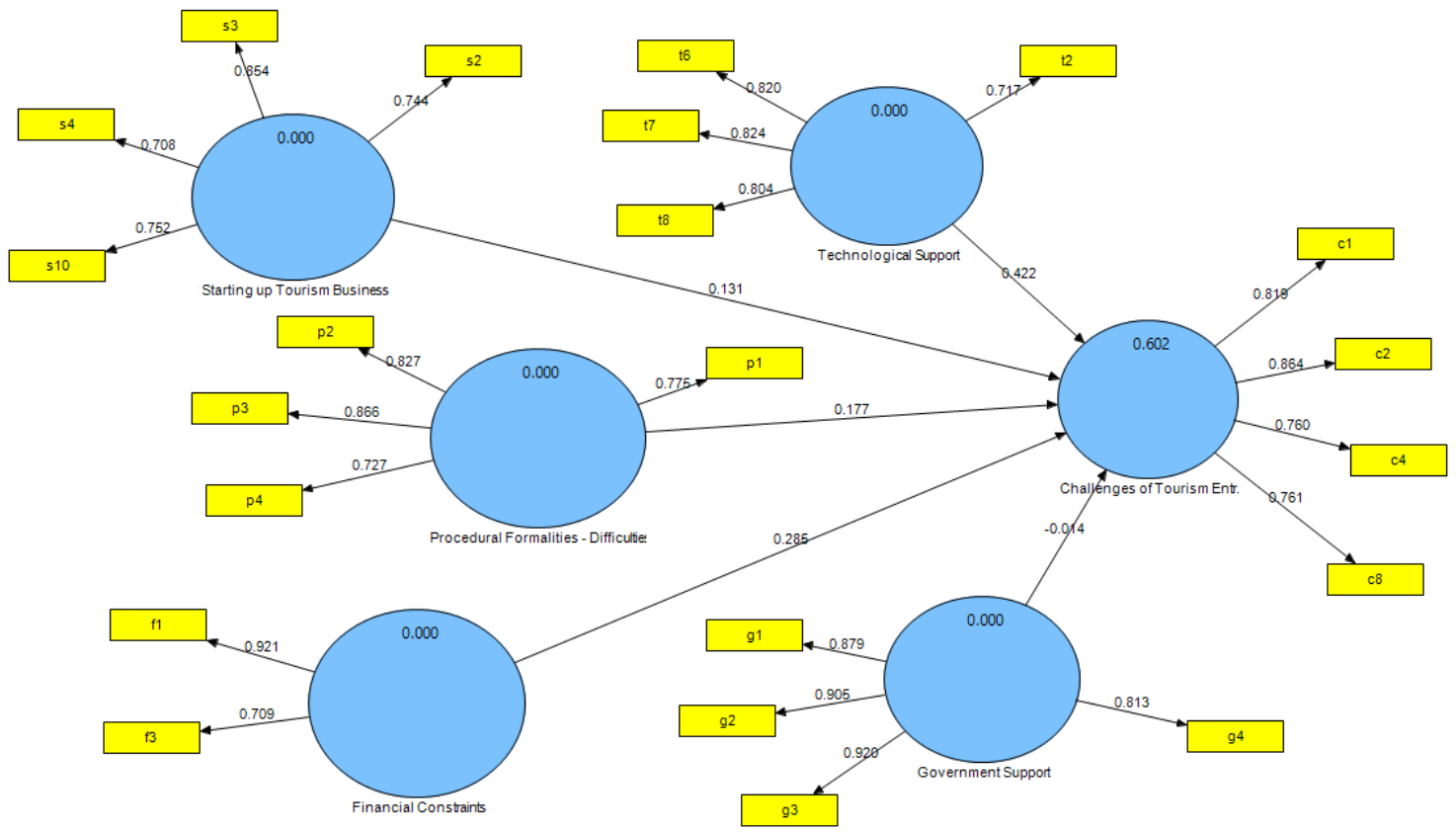

\section{Reliability}

Construct reliability and inner consistency were adjudged using composite reliability as it is more appropriate compared to Cronbachs Alpha (Hulland, 1999). As per Hair, Sarstedt, Ringle, and Mena (2012), the least score for composite reliability should be 0.7 and as per Gefen, Straub, and Boudreau (2000), the minimum score for Cronbachs alpha should be 0.6. The factor loadings, composite reliability and Cronbachs alpha values obtained through PLS algorithms were shown in Table 4 . As can be seen, Cronbachs alpha value was above 0.755 except Obsessive Passion qualities. It was also seen that the composite reliability score was more than 0.799 except the score of the Obsessive Passion qualities which was close to 0.70 . Therefore, the model can be considered trustworthy.

Table 4

Factor loading for indicators of latent constructs

\begin{tabular}{|c|c|c|c|c|c|}
\hline & Factors and Sub-factors & $\begin{array}{l}\text { Factor } \\
\text { loading }\end{array}$ & $\begin{array}{l}\text { Cronbachs } \\
\text { alpha }\end{array}$ & $\begin{array}{l}\text { Composite } \\
\text { reliability }\end{array}$ & AVE \\
\hline $\mathbf{C}$ & $\begin{array}{l}\text { Challenges faced by Tourism } \\
\text { entrepreneurs }\end{array}$ & & 0.814614 & 0.87819 & 0.64384 \\
\hline $\mathrm{c} 1$ & $\begin{array}{l}\text { Lack of interest in tourism is a real } \\
\text { challenge in the tourism business in } \\
\text { Oman }\end{array}$ & 0.819208 & & & \\
\hline $\mathrm{c} 2$ & $\begin{array}{l}\text { Lack of commitment and ignorance } \\
\text { harms the tourism business }\end{array}$ & 0.86432 & & & \\
\hline $\mathrm{c} 4$ & $\begin{array}{l}\text { Financial factors such as initial } \\
\text { capital, working capital affect the } \\
\text { tourism business }\end{array}$ & 0.760273 & & & \\
\hline $\mathrm{c} 8$ & $\begin{array}{l}\text { Spouse preferences from the non- } \\
\text { tourism sector is a constraint for } \\
\text { Omanis in taking up tourism } \\
\text { businesses }\end{array}$ & 0.761042 & & & \\
\hline $\mathbf{F}$ & Financial constraints & & 0.548618 & 0.80352 & 0.67528 \\
\hline f1 & $\begin{array}{l}\text { Capital is a major concern in } \\
\text { starting a tourism business }\end{array}$ & 0.9211 & & & \\
\hline f3 & $\begin{array}{l}\text { Financial Institutions (FIs) insist } \\
\text { for guarantees from the borrowers } \\
\text { of tourism businesses }\end{array}$ & 0.70862 & & & \\
\hline $\mathbf{G}$ & Government Support factors & & 0.811245 & 0.8848 & 0.719797 \\
\hline g1 & $\begin{array}{l}\text { The Government should build } \\
\text { synergy between private and public }\end{array}$ & 0.8794 & & & \\
\hline
\end{tabular}




\begin{tabular}{|c|c|c|c|c|c|}
\hline & $\begin{array}{l}\text { sector to boost tourism business in } \\
\text { Oman }\end{array}$ & & & & \\
\hline g2 & $\begin{array}{l}\text { The Government should provide } \\
\text { strategic support to the tourism- } \\
\text { related entrepreneurs }\end{array}$ & 0.90542 & & & \\
\hline g3 & $\begin{array}{l}\text { The Government should provide } \\
\text { Capital/Loans for tourism } \\
\text { entrepreneurs on easy terms \& } \\
\text { conditions }\end{array}$ & 0.92039 & & & \\
\hline $\mathrm{g} 4$ & $\begin{array}{l}\text { The Government should provide } \\
\text { financial guidance to encourage } \\
\text { tourism entrepreneurs irrespective } \\
\text { of their age }\end{array}$ & 0.81331 & & & \\
\hline $\mathbf{P}$ & $\begin{array}{l}\text { Procedures and Formality - } \\
\text { Difficulties }\end{array}$ & & 0.811468 & 0.87655 & 0.64066 \\
\hline $\mathrm{p} 1$ & $\begin{array}{l}\text { Prevailing rules and regulations are } \\
\text { strict and rigid to start a tourism } \\
\text { business in Oman }\end{array}$ & 0.77501 & & & \\
\hline p2 & $\begin{array}{l}\text { It takes lots of time to start the } \\
\text { operation of tourism-related } \\
\text { business }\end{array}$ & 0.82727 & & & \\
\hline p3 & $\begin{array}{l}\text { The formalities set up by the } \\
\text { municipality to start a tourism } \\
\text { business is cumbersome }\end{array}$ & 0.86584 & & & \\
\hline $\mathrm{p} 4$ & $\begin{array}{l}\text { There is no inter-link between the } \\
\text { Governmental licensing authorities }\end{array}$ & 0.72661 & & & \\
\hline $\mathbf{S}$ & Starting Tourism Business & & 0.764838 & 0.85006 & 0.58754 \\
\hline s2 & $\begin{array}{l}\text { Starting a tourism-related business } \\
\text { could help Oman's Economy }\end{array}$ & 0.74391 & & & \\
\hline s3 & $\begin{array}{l}\text { Oman has the three necessaries for } \\
\text { tourism - Sun, Sea, and Scene to } \\
\text { justify the scope of tourism } \\
\text { business }\end{array}$ & 0.85435 & & & \\
\hline s4 & $\begin{array}{l}\text { There are lots of chances to venture } \\
\text { into the tourism business }\end{array}$ & 0.70759 & & & \\
\hline s10 & $\begin{array}{l}\text { Women venturing in the tourism } \\
\text { industry could help in improving } \\
\text { the economy of the country }\end{array}$ & 0.75244 & & & \\
\hline $\mathbf{T}$ & Technological Support factors & & 0.802642 & 0.87062 & 0.62789 \\
\hline $\mathrm{t} 2$ & $\begin{array}{l}\text { Investors and stakeholders would } \\
\text { be benefitted through tourism } \\
\text { promotion made by the media }\end{array}$ & 0.71697 & & & \\
\hline t6 & $\begin{array}{l}\text { Infrastructure in Oman needs } \\
\text { modernization to attract tourists }\end{array}$ & 0.81984 & & & \\
\hline $\mathrm{t} 7$ & $\begin{array}{l}\text { Technology improvement helps to } \\
\text { increase tourist satisfaction }\end{array}$ & 0.82388 & & & \\
\hline t8 & $\begin{array}{l}\text { Using technology in tourism } \\
\text { business can increase their income }\end{array}$ & 0.80411 & & & \\
\hline
\end{tabular}

\section{Convergent Validity and Average Variance Extracted (AVE)}

To assess convergent validity

i) the outer loadings should be greater than or equal to 0.70 (Hair, Black, Babin, Anderson, \& Tatham, 1998) and

ii) AVE values for every latent variable should be more than 0.50 (Hulland, 1999). 0.4 is acceptable (Bagozzi \& Yi, 1988) if composite reliability is more than 0.6 (Fornell \& Larcker, 1981).

From Table. 4 it can be seen that the average variance extracted ranged from 0.58754 to 0.719797 , and thus the convergent validity is satisfactory.

Discriminant Validity 
Discriminant validity is to ensure that a construct (latent variable) has the strongest relationships than any other construct in the PLS path model. The values of the AVE square root and constructs correlations in Table 5 shows that the constructs Discriminant validity is satisfactory.

Table 5

Discriminant Validity Results

\begin{tabular}{|c|c|c|c|c|c|c|}
\hline & $\begin{array}{l}\text { Client- } \\
\text { related } \\
\text { factors }\end{array}$ & $\begin{array}{l}\text { Contractor } \\
\text { related } \\
\text { factors }\end{array}$ & $\begin{array}{l}\text { Equipment- } \\
\text { related } \\
\text { factors }\end{array}$ & $\begin{array}{l}\text { Labor- } \\
\text { related } \\
\text { factors }\end{array}$ & $\begin{array}{l}\text { Material } \\
\text { related } \\
\text { factors }\end{array}$ & $\begin{array}{l}\text { Project } \\
\text { Completion } \\
\text { Delay } \\
\text { factors }\end{array}$ \\
\hline $\begin{array}{l}\text { Challenges of } \\
\text { Tourism } \\
\text { Entrepreneurs }\end{array}$ & 1 & & & & & \\
\hline $\begin{array}{l}\text { Financial } \\
\text { constraints }\end{array}$ & 0.573379 & 1 & & & & \\
\hline $\begin{array}{l}\text { Government } \\
\text { support }\end{array}$ & 0.504048 & 0.27653 & 1 & & & \\
\hline $\begin{array}{l}\text { Procedural } \\
\text { Formalities - } \\
\text { Difficulties }\end{array}$ & 0.554352 & 0.54303 & 0.409 & 1 & & \\
\hline $\begin{array}{l}\text { Starting up } \\
\text { Tourism } \\
\text { Business }\end{array}$ & 0.527941 & 0.30968 & 0.66838 & 0.46829 & 1 & \\
\hline $\begin{array}{l}\text { Technological } \\
\text { support }\end{array}$ & 0.660241 & 0.36758 & 0.66183 & 0.39476 & 0.55695 & 1 \\
\hline
\end{tabular}

\section{Structural Model Analysis}

Through the path coefficient values, the relationship among the R-square value, independent variable, and dependent variable is tested. The values obtained through the bootstrapping test using PLS are shown in Table 6.

Table 6

Path coefficients along with their Bootstrap values and T-values

\begin{tabular}{|c|c|c|c|c|c|c|c|}
\hline Factors & $\begin{array}{c}\text { Original } \\
\text { Sample } \\
(0)\end{array}$ & $\begin{array}{c}\text { Sample } \\
\text { Mean } \\
\text { (M) }\end{array}$ & $\begin{array}{l}\text { Standard } \\
\text { Deviation } \\
\text { (STDEV) }\end{array}$ & $\begin{array}{c}\text { Standard } \\
\text { Error } \\
\text { (STERR) }\end{array}$ & $\begin{array}{l}\text { T Statistics } \\
(\mid \text { O/STERR|) }\end{array}$ & $\begin{array}{l}\text { Suppor } \\
\text { ted }\end{array}$ & $\begin{array}{c}\text { Significance } \\
\text { values }\end{array}$ \\
\hline $\begin{array}{l}\text { Financial } \\
\text { constraints > } \\
\text { Challenges of } \\
\text { Tourism } \\
\text { Entrepreneurs }\end{array}$ & 0.285417 & 0.28604 & 0.06029 & 0.06029 & 4.7338 & Yes & $\begin{array}{c}\mathrm{p}<0.05 \\
1.96\end{array}$ \\
\hline $\begin{array}{l}\text { Government } \\
\text { support > } \\
\text { Challenges of } \\
\text { Tourism } \\
\text { Entrepreneurs }\end{array}$ & -0.014052 & -0.00378 & 0.07589 & 0.07589 & 0.18517 & No & --- \\
\hline $\begin{array}{l}\text { Procedural } \\
\text { Formalities - } \\
\text { Difficulties > } \\
\text { Challenges of } \\
\text { Tourism } \\
\text { Entrepreneurs }\end{array}$ & 0.17727 & 0.17161 & 0.07278 & 0.07278 & 2.43572 & Yes & $\begin{array}{c}\mathrm{p}<0.05 \\
1.96\end{array}$ \\
\hline $\begin{array}{l}\text { Starting up } \\
\text { Tourism } \\
\text { Business > } \\
\text { Challenges of } \\
\text { Tourism } \\
\text { Entrepreneurs }\end{array}$ & 0.131105 & 0.13448 & 0.06728 & 0.06728 & 1.9486 & No & --- \\
\hline
\end{tabular}




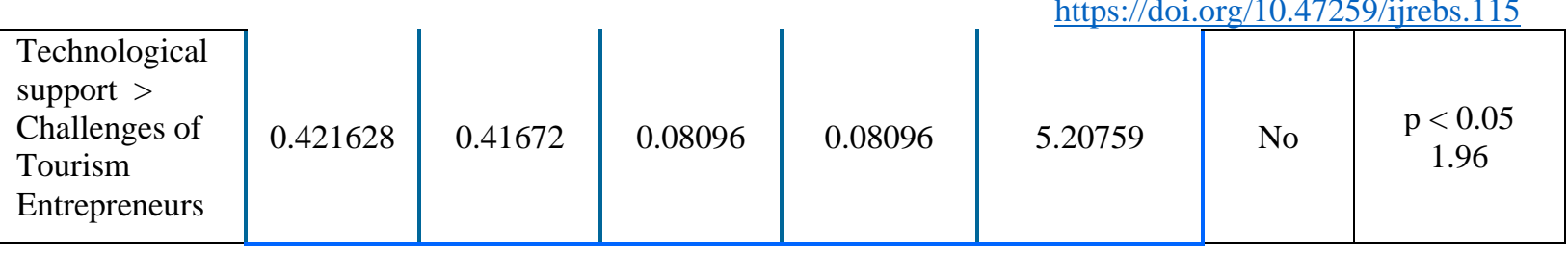

The relationship between the Financial constraints factors and the Challenges of Tourism Entrepreneurship factors was supported and significant as $\beta=0.285417$ and t-value $=4.7338(>1.96)$ at the significance of $p$ at 0.05 level, which indicated that the Challenges of Tourism Entrepreneurship was positively influenced by the Financial constraints.

The relationship between the Government support factors and the Challenges of Tourism Entrepreneurship factors was insignificant with $\beta=-0.0014052$ and $\mathrm{t}$-value $=0.18517(<1.96)$ which indicates that the Challenges of Tourism Entrepreneurship did not influence by Government support.

The relationship between the Procedural and Formality - Difficulties factors and Challenges of Tourism Entrepreneurship factors was supported and significant as $\beta=0.17727$ and $t$-value $=2.43572(>1.96)$ at the significance of $\mathrm{p}$ at 0.05 level, which indicated that the Challenges of Tourism Entrepreneurship was influenced directly and positively by Procedural and Formalities - Difficulties.

The relationship between the Starting up of Tourism Business factors and Challenges of Tourism Entrepreneurship factors was insignificant with $\beta=0.131105$ and $t$-value $=1.9486(<1.96)$ which indicates that the Challenges of Tourism Entrepreneurship did not influence by Starting up of Tourism Business.

The relationship between the Technological Support factors and Challenges of Tourism Entrepreneurship factors was significant with $\beta=0.421628$ and t-value $=5.20759(>1.96)$ which indicates that the Challenges of Tourism Entrepreneurship was influenced directly and positively by Technological Support.

In other words, the Challenges of Tourism Entrepreneurship was positively influenced by the Financial constraints, Procedural and Formality - Difficulties, and Technological Support, i.e. Hypothesis. 1 is proved positively.

\section{Figure 4}

Bootstrapping Diagram

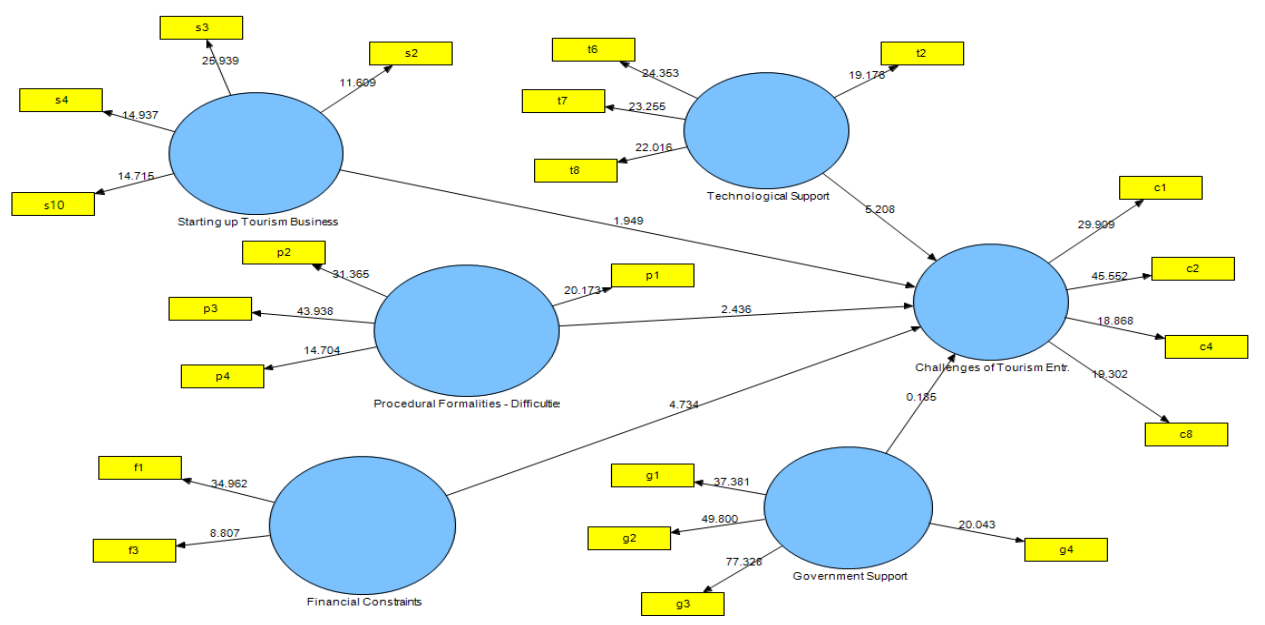

Assessment of Fit

Goodness-of-fit (GOF) is the overall model fit for PLSEM.

$\mathrm{GOF}=\sqrt{\text { average }} \mathrm{R}^{2 *}$ average communality $=\sqrt{ } 0.602431 \times 0.6584395=0.629813$

Table 7

Model Evaluation Results

\begin{tabular}{|l|c|c|c|c|c|}
\hline \multicolumn{1}{|c|}{ Factors } & $\mathbf{R}^{\mathbf{2}}$ & Communality & $\mathbf{H}^{\mathbf{2}}$ & Redundancy & $\mathbf{F}^{\mathbf{2}}$ \\
\hline $\begin{array}{l}\text { Challenges of } \\
\begin{array}{l}\text { Tourism } \\
\text { Entrepreneurship }\end{array}\end{array}$ & 0.602431 & 0.64384 & 0.402 & 0.158465 & 0.365 \\
\hline
\end{tabular}


International Journal of Research in Entrepreneurship \& Business Studies elSSN-2708-8006, Vol. 1, issue. 1, 2020, pp. 48-64

\begin{tabular}{|c|c|c|c|c|c|}
\hline $\begin{array}{l}\text { Financial } \\
\text { constraints }\end{array}$ & & 0.67528 & 0.124 & & 0.124 \\
\hline $\begin{array}{l}\text { Government } \\
\text { support }\end{array}$ & & 0.77543 & 0.613 & & 0.613 \\
\hline $\begin{array}{l}\text { Procedural } \\
\text { Formalities } \\
\text { Difficulties }\end{array}$ & & 0.64066 & 0.414 & & 0.414 \\
\hline $\begin{array}{l}\text { Starting up } \\
\text { Tourism Business }\end{array}$ & & 0.58754 & 0.314 & & 0.314 \\
\hline $\begin{array}{l}\text { Technological } \\
\text { Support }\end{array}$ & & 0.62789 & 0.371 & & 0.371 \\
\hline & 0.602431 & 0.6584395 & 0.373 & 0.158465 & 0.36683 \\
\hline \multicolumn{6}{|c|}{$\begin{array}{l}\text { GOF - } \sqrt{\text { average }} \mathrm{R}^{2} \mathrm{x} \text { average communality }=\sqrt{0.602431 \times 0.6584395}=0.629813 \\
\text { Where } \mathrm{H}^{2} \text { is } \mathrm{CV} \text {-communality index and } \mathrm{F}^{2} \text { is } \mathrm{CV} \text {-redundancy index }\end{array}$} \\
\hline
\end{tabular}

In PLS, structural model and hypothesis were tested by computing path coefficients $\beta$ as PLS does not require a normally distributed data, it is evaluated with $\mathrm{R}^{2}$ calculation for dependent latent variables (Huang, Wang, $\mathrm{Wu}, \&$ Wang, 2013) and the Average Variance Extracted (Cohen, West, \& Aiken, 2014). $\mathrm{R}^{2}$ measures a construct's percent variation that is explained by the model (Wixom \& Watson, 2001). A value greater than zero means the model has predictive significance, whereas value lesser than 0 mean that the model lacks predictive significance as presented in Figure 5.

\section{Figure 5}

\section{Blind Folding Path Diagram}

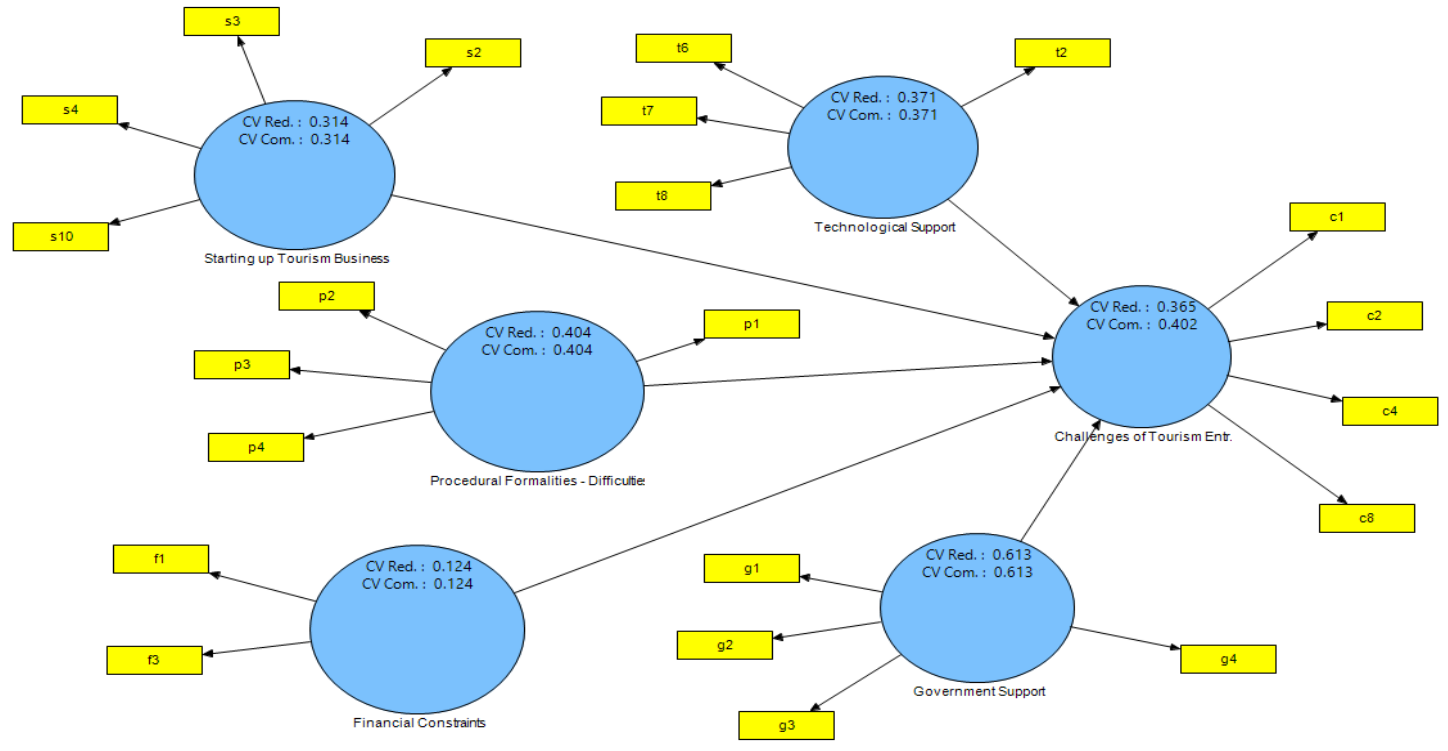

\section{Discussion}

\section{Initial Setup}

Most of the respondents $(78 \%)$ believe that Oman has the high potential to set up a tourism business and tourism-related business could help Oman's economy towards diversification. It is also observed that women who lack moral support, are also interested to venture into the tourism industry as they are motivated to establish tourism business in Oman. Hypothesis No.2 proved positively.

Challenges of Tourism Entrepreneurship was positively influenced by the Financial constraints, Procedural and Formality - Difficulties, and Technological Support whereas it is not influenced by Government support and Starting up factors.

\section{Financial constraints}

Most of the respondents stated that the initial capital was the major concern for starting a tourism business and they confirmed that the financial institutions (FIs) insist on guarantees from the borrowers for tourism businesses. 


\section{Procedural and Formality - Difficulties}

Most of the respondents agreed that the prevailing rules and regulations are strict and rigid to start a tourism business in Oman and the formalities set up by the municipality to start a tourism business is cumbersome. They claimed that it took lots of time to start the operation of a tourism-related business and there is no interlink between the Governmental licensing authorities

\section{Technological Support}

Most of the respondents agreed that technological support helps to increase tourist satisfaction and thereby the income of tourism businesses. They claimed that the infrastructure in Oman needs modernization to attract tourists, and the investors and stakeholders in Tourism would be benefitted through media promotion.

\section{Challenges faced}

Lack of interest in tourism is a real challenge in the tourism business in Oman and the lack of commitment and ignorance harms the tourism business. Spouse preferences from the non-tourism sector is a constraint for Omanis in taking up tourism businesses. Besides all, financial factors such as initial capital, working capital affect the tourism business a lot.

\section{Conclusion}

It can be seen from the above that the respondents confirmed Initial Capital and Working capital and Good Location are the primary essential factors required by them to establish a tourism business in Oman. They confirmed that Oman has a great scope to start a tourism-related business and starting a tourism-related business could help Oman's Economy. As Oman has the three necessaries for tourism - Sun, Sea, and Scene to justify the scope of tourism business they claim that there are lots of chances to venture into the tourism business. As Oman has nice tourist places to visit throughout the year, the Investors and stakeholders would be benefitted through tourism. However, costly hotels and restaurants discourage tourists from visiting Oman and the poor transportation facility is a big challenge in promoting tourism in Oman. The Government should provide strategic support to tourism entrepreneurs and the Government should provide Capital/Loans for tourism entrepreneurs.

In general, the respondents confirmed that the prevailing rules and regulations are strict and rigid to start a tourism business in Oman and it takes a lot of time to start the operation of tourism-related businesses; the formalities set up by the municipality to start tourism business is cumbersome; seeking labor clearance procedure is NOT simple for tourism. Further, the labor clearance authorities will not sanction a sufficient number of workers for the tourism business.

Social factors such as age, level of education, population growth rate, etc. are making a negative impact on the tourism business. Further, Gender discrimination also prevails in tourism-related businesses. Besides, Oman's cultural values and physical working conditions do not encourage tourism-related businesses. The English language is another challenge as local Omanis find difficulty in speaking with international tourists. Besides all, gender discrimination prevails in tourism businesses. Women entrepreneurs lack moral support towards tourism start-ups as they do not get recognition/support from the society in starting a business related to tourism. Women entrepreneurs in tourism also lack initial capital to start a business in tourism.

Last but not the least, non-preference of Spouse from the tourism sector is another major constraint for Omanis in taking up businesses in the tourism sector.

\section{Suggestions}

Based on the above, the following suggestions are made:

1. Using technology in tourism business can increase the income

2. Technology improvement will enhance tourist satisfaction, and investors and stakeholders in tourism would be benefitted through the media.

3. There is no inter-link between the Governmental licensing authorities and all licenses to set up tourism business need to be obtained in one place.

4. The Government should provide strategic support to tourism-related entrepreneurs.

5. The Government should provide financial guidance to encourage tourism entrepreneurs irrespective of their ages.

6. The Government should invest in super-structure projects to enhance the scope of tourism.

7. Training must be provided by the Government to enhance the tourism business in Oman.

\section{References}


Adewale, A.A. (2016). The Task, Challenges and Strategies for the Marketing of Tourism and Relaxation Services in Nigeria. International Journal of Marketing Practices, 3(1), 24-32. doi: http://doi.org/10.20448/806.3.1.24.32

Al Abri, S.S., Abdel-Hady, D.M., \& Al-Abaidani, I.S. (2016). Knowledge, Attitudes, and Practices regarding travel health among Muscat International Airport Travelers in Oman: Identifying the gaps and addressing the Challenges. Journal of Epidemiology and Global Health, 6(2), 67-75. doi: http://doi.org/10.1016/j.jegh.2016.02.003

Al Badi, A.H., Malik, A., \& Gastli, A. (2009). Assessment of Renewal Energy Resources Potential in Oman and Identification of Barrier to their Significant Utilization. Renewable and Sustainable Energy Reviews. 13(9), 2734-2739.

Al Buraiki, A., \& Khan, F. R. (2018). Finance and Technology: Key Challenges faced by Small and Medium Enterprises (SMEs) in Oman. International Journal of Management, Innovation \& Entrepreneurial Research, 4(2), 1-12. doi: http://doi.org/10.18510/ijmier.2018.421

Al Harthi, A.S.A. (2017). Understanding Entrepreneurship through the Experiences of Omani Entrepreneurs: Implications for Entrepreneurship Education. Journal of Developmental Entrepreneurship, 22(01), 1750001. doi: http://doi.org/10.1142/S1084946717500017

Al Hadhrami, Z. (2006). The Impact of GCC Integration on the Economy of Oman: An Empirical Study of the Business Community to the Customs Union, Doctoral Dissertation, Durham University.

Al Mahrooqi, R. (2012). A student perspective on low English proficiency in Oman. International Education Studies, 5(6), 263-271.

Al Muqbali, A. H. (2006). Towards More Effective Administrative Training in the Omani Public Sector. Doctoral Dissertation presented to the School of Education, University of Manchester, U.K.

Al Riyami, H., Scott, N. Ragab, A. M. \& Jafari, J. (2017). Evaluating Ecotourism Challenges in Oman. International Tourism Development and the Gulf Cooperation Council States. Challenges and Opportunities, 156-168.

Alani, F., Khan, F. R., \& Manuel, D. (2017). Need for Professionalism and Quality Service of the Tourist Guides in Oman. International Journal of Tourism \& Hospitality Reviews, 4(1), 20-29. doi: http://doi.org/10.18510/ijthr.2017.413

Ali, Y., Nusair, M. M., Alani, F., Khan, F. R., \& Al Badi, L. (2017). Employment in the private sector in Oman: Sector-based approach for localization. Humanities \& Social Sciences Reviews, 5(1), 1-20. doi: https://doi.org/10.18510/hssr.2017.511

AlMaimani, J., \& Johari, F. B. (2014). Tourism Development Plan in Oman. Indicator, 2015, 2016p.

Alrawadieh, Z., Karayilan, E., \& Cetin, G. (2019). Understanding the challenges of refugee entrepreneurship in tourism and hospitality. The Service Industries Journal, 39(9-10), 717-740. doi: http://doi.org/10.1080/02642069.2018.1440550

Alsawafi, A. M. (2016). Exploring the challenges and perceptions of Al Rustaq College of Applied Sciences students towards Omani women's empowerment in the tourism sector. Tourism Management Perspectives, 20, 246-250.

Atef, T. M., \& Al-Balushi, M. (2015). Entrepreneurship as a means for restructuring employment patterns. Tourism and Hospitality Research, 15(2), 73-90. doi: http://doi.org/10.1177/1467358414558082

Atembe, R. (2015). The use of smart technology in tourism: Evidence from wearable devices. Journal of Tourism and Hospitality Management, 3(11-12), 224-234. doi: http:/doi.org/10.17265/23282169/2015.12.002

Aulia, S. (2016). The Challenges of Tourism- With Specific Reference to Muscat Region (A Conceptual Perspective. International Journal of Research in Tourism and Hospitality, 2(4), 1-4. doi: http://doi.org/10.20431/2455-0043.0204001

Bagozzi, R. P., \& Yi, Y. (1988). On the evaluation of structural equation models. Journal of the academy of marketing science, 16(1), 74-94. doi: https://doi.org/10.1007/BF02723327

Baporikar, N. (2017). Critical review of entrepreneurship in Oman Entrepreneurship and Business Innovation in the Middle East (pp. 147-174): IGI Global.

Binoy, T.A. (2017). Dynamics of Medical Tourism In India - a microscopic Analysis. Asia Pacific Journal of Research, 1(58), 161-167.

Brdesee, H. (2013). Exploring factors impacting e-commerce adoption in tourism industry in Saudi Arabia, Doctoral Dissertation, Business, IT and Logistics, RMIT University.

Buhalis, D., \& Law, R. (2008). Progress in information technology and tourism management: 20 years on and 10 years after the Internet-The state of eTourism research. Tourism Management, 29(4), 609-623. doi: https://doi.org/10.1016/j.tourman.2008.01.005

Cohen, P., West, S. G., \& Aiken, L. S. (2014). Applied multiple regression/correlation analysis for the behavioral sciences: Psychology Press.

Comrey, A. L., \& Lee, H. B. (2013). A first course in factor analysis: Psychology press. 
Fornell, C., \& Larcker, D. F. (1981). Evaluating structural equation models with unobservable variables and measurement error. Journal of marketing research, 18(1), 39-50. doi: https://doi.org/10.1177/002224378101800104

Frew, A. J. (2000). Information and communications technology research in the travel and tourism domain: Perspective and direction. Journal of Travel Research, 39(2), 136-145. doi: https://doi.org/10.1177/004728750003900203

Gefen, D., Straub, D., \& Boudreau, M.-C. (2000). Structural equation modeling and regression: Guidelines for research practice. Communications of the association for information systems, 4(1), 1-78. doi: https://doi.org/10.17705/1CAIS.00407

Ghouse, S., McElwee, G., Meaton, J., \& Durrah, O. (2017). Barriers to rural women entrepreneurs in Oman. International Journal of Entrepreneurial Behavior \& Research, 23(6), 998-1016. doi: http://doi.org/10.1108/IJEBR-02-2017-0070

Hair, J. F., Black, W. C., Babin, B. J., Anderson, R. E., \& Tatham, R. L. (1998). Multivariate data analysis (Vol. 5, No. 3, pp. 207-219): Upper Saddle River, NJ: Prentice-Hall.

Hair, J. F., Sarstedt, M., Ringle, C. M., \& Mena, J. A. (2012). An assessment of the use of partial least squares structural equation modeling in marketing research. Journal of the academy of marketing science, 40(3), 414-433. doi: https://doi.org/10.1007/s11747-011-0261-6

Henderson, D., Sheetz, S. D., \& Trinkle, B. S. (2012). The determinants of inter-organizational and internal in-house adoption of XBRL: A structural equation model. International journal of accounting information systems, 13(2), 109-140. doi: https://doi.org/10.1016/j.accinf.2012.02.001

Henderson, J. C. (2005). Responding to natural disasters: Managing a hotel in the aftermath of the Indian Ocean tsunami. Tourism and Hospitality Research, 6(1), 89-96.

Huang, C.-C., Wang, Y.-M., Wu, T.-W., \& Wang, P.-A. (2013). An empirical analysis of the antecedents and performance consequences of using the Moodle platform. International Journal of Information and Education Technology, 3(2), 217. doi: http://doi.org/10.7763/IJIET.2013.V3.267

Hulland, J. (1999). Use of partial least squares (PLS) in strategic management research: A review of four recent studies. Strategic management journal, 20(2), 195-204.

Khan, F. R., \& Krishnamurthy, J. (2016). Future-proofing of tourism entrepreneurship in Oman: challenges and prospects. Journal of Work-Applied Management, 8(1), 79-94. doi: http://doi.org/10.1108/JWAM-06-2016-0008

Kim, D., \& Kim, S. (2017). The role of mobile technology in tourism: Patents, articles, news, and mobile tour app reviews. Sustainability, 9(11), 2082. doi: http://www.doi.org/10.3390/su9112082

Mansour, S., Al-Awhadi, T., \& Al-Hatrushi, S. (2020). Geospatial based multi-criteria analysis for ecotourism land suitability using GIS \& AHP: a case study of Masirah Island, Oman. Journal of Ecotourism, 19(2), 148-167.

Ozturk, H. M. (2020). Technological Developments: Industry 4.0 and Its Effect on the Tourism Sector. In Handbook of Research on Smart Technology Applications in the Tourism Industry (pp. 205228). IGI Global.

Pandow, B. A., \& Omar, A. S. (2019). Evaluating Inclination of Youth to Start Enterprise: A Study in Oman Creative Business and Social Innovations for a Sustainable Future (pp. 133-142): Springer.

Saleh, M. S., \& Alalouch, C. (2015). Towards sustainable construction in Oman: Challenges \& opportunities. Procedia Engineering, 118, 177-184. doi: http://doi.org/10.1016/j.proeng.2015.08.416

Sazegar, M., Forouharfar, A., Hill, V., \& Faghih, N. (2018). The innovation-based competitive advantage in Oman's transition to a knowledge-based economy: dynamics of innovation for promotion of entrepreneurship Entrepreneurship Ecosystem in the Middle East and North Africa (MENA) (491518): Springer.

Subramoniam, S., Al-Essai, S. A. N., Al-Marashadi, A. A. M., \& Al-Kindi, A. M. A. (2010). SWOT analysis on Oman tourism: A case study. Journal of Economic Development, Management, IT, Finance, and Marketing, 2(2), 1-22.

Sokhalingam, C., Manimekalai, N., \& Sudhahar, C. (2013). Entrepreneurial approach to tourism development in Oman. International Journal of Management, 4(3), 48-60.

Sotiriadis, M., \& Apostolakis, A. (2015). Marketing challenges in travel, tourism and hospitality industries of the European and Mediterranean regions. EuroMed Journal of Business, 10(3), 1-3. doi: http://doi.org/10.1108/EMJB-07-2015-0035

Stanković, L., \& Đukić, S. (2009). Challenges of strategic marketing of tourist destination under the crisis conditions. Facta Universitatis, Series: Economics and Organization, 6(1), 23-31.

Tenenhaus, M., Vinzi, V. E., Chatelin, Y.-M., \& Lauro, C. (2005). PLS path modeling. Computational statistics \& data analysis, 48(1), 159-205. doi: https://doi.org/10.1016/j.csda.2004.03.005 
Tewari, V. (2019). Seasonality in tourism: the case of Oman. Ottoman: Journal of Tourism and Management Research, 4(2), 463-476. doi: http://doi.org/10.26465/ojtmr.2018339522

THR Innovative Tourism Advisors. (2016). Oman Tourism Strategy - Executive Summary. (Document No.309). Muscat: Innovative Tourism Advisors for Ministry of Tourism of the Sultanate of Oman

Urbančič, J., Kuralt, V., Ratkajec, H., Straus, M., Vavroš, A., Mokorel, S., ... \& Ilijaš, T. (2020). Expansion of Technology Utilization Through Tourism 4.0 in Slovenia. In Handbook of Research on Smart Technology Applications in the Tourism Industry (pp. 229-253). IGI Global.

Vidal, B. (2019). The New Technology and Travel Revolution. WAM Global Growth Agents, Business Intelligence \& Analytics. https://www.wearemarketing.com/blog/tourism-and-technology-howtech-is-revolutionizing-travel.html

Yuksel, S. (2014). Roadmap Of Recovery Amid Challenges Facing Oman Tourism. OJAS, 5(1), 1-14.

Copyright: () 2020 by the authors. Licensee Global Scientific Publications, Oman.

This work is licensed under a Creative Commons Attribution-ShareAlike 4.0 International License.

This is an open-access journal and the articles published in this journal are distributed under the terms of CC-BY-SA. 